Kong. Res. J. 3(2) : 59-61, 2016

ISSN 2349-2694

Kongunadu Arts and Science College, Coimbatore.

\title{
ANTIBACTERIAL ACTIVITY LEAF EXTRACTS OF STRYCHNOS NUX VOMICA L. - A MEMBER OF LOGANIACEAE
}

\author{
Nantha Kumar, $R^{*}$., H. Abdul Kaffoor and K. Arumugasamy \\ PG and Research Department of Botany, Kongunadu Arts and Science College (Autonomous), Coimbatore. \\ *E.mail: nanthavkm@gmail.com
}

\begin{abstract}
The present study investigates the antibacterial activity of various solvents leaf extracts of Strychnos nux vomica against four different bactria strains like Bacillus subtilis, Escherichia coli, Pseudomonas aeruginosa, Salmonella paratyphi $b$, Alternaria alternate, Aspergillus flavus, Penicillium notatum and Cladosporium carrionii. All the results were compared with respective positive control.
\end{abstract}

Keywords: Strychnos nux vomica, antimicrobial activity.

\section{INTRODUCTION}

Medicinal plants are rich in traditional knowledge drastically recede in the wake of burgeoning population pressure, acculturation, rapid modernization, multi various human developmental activities. A lot of current research work in ethnobotany is concerned with the loss of traditional knowledge and the preservation of biological diversity in remote parts of the world where cultures and their ecosystems are being destroyed by development (Sereiti et al., 1999). The ethnobotanical investigations may become invaluable to rescue knowledge in imminent danger of being lost and to find out new bioactive compounds in plant. The use of plant preparations as foodstuff, insecticides, CNS active, cardio active, antitumor and antimicrobial agents are some examples of immense chemical diversity in plants (Balick et al.,2000).

The phytochemical techniques various active principles of many medicinal plants have been isolated and introduced as valuable drugs in morden system of medicine (Dennis,1988). Strychnos nux vomica is an evergreen tree native to South East Asia and India belonging to the family Loganiaceae. It is medium sized tree found mostly in open habitats. Two poisonous alkaloids, Strychnine and brucine are found in Strychnos nux vomica tree. Traditionally used for treating acute diarrhoea, mixed with lemon juice and made into pills and taken orally during dysentery, arthritis, rheumatism and piles (Dubey et al.,2012).

\section{MATERIALS AND METHODS}

\subsection{Plant collection and identification}

The plant Strychnos nux vomica was collected from the Nilgiris, Tamilnadu, India. The plant was identified and authenticated by a plant taxonomist.

\subsection{Extraction of the plant material}

About $250 \mathrm{~g}$ of freshly collected sample of Strychnos nux vomica (leaf) was separately washed 2-3 times with water followed by distilled water and shade dried. All the dried parts were pulverized by mechanical grinder (willey mill) to get the powder through 100 mess sieve and then stored in a refrigerator. It was extracted by cold extraction method with petroleum ether, ethanol, methanol and aqueous. Then all the extracts were concentrated in a rotary evaporator to yield a syrupy residue and used for all the phytochemical analysis.

\subsection{Tested Microorganisms}

Bacterial strains Bacillus subtilis, Escherichia coli, Pseudomonas aeruginosa, Salmonella paratyphi b.

\subsection{Disc diffusion method}

The antibacterial activity of leaves extracts of Strychnos nux vomica was evaluated by disc diffusion method. The culture media were prepared and autoclaved at $121^{\circ} \mathrm{C}$ at $15 \mathrm{psi}$ for 20 minutes and stored in refrigerator. The media were melted before the process of inoculation. The clean dry sterile Petri dishes were poured with nutrient agar medium for bacterial strains. Ten number of $10 \mathrm{ml}$ broths were prepared separately for nutrient agar medium in test tubes and plugged with cotton and autoclaved. The test tubes were labeled according to the microbes to 
be inoculated. The bacterial strains were inoculated into the nutrient broth aseptic conditions and incubated at $37+0.5^{\circ} \mathrm{C}$ for 18 hours. After incubation, the bacteria were smeared on the nutrient agar plate respectively using a sterile cotton swab. A sterile disc of $6 \mathrm{~mm}$ diameter was loaded with known quantity of $10 \mathrm{mg}$ of dried crude extracts of aqueous, petroleum ether, ethanol and methanol extracts and dissolved in $10 \mathrm{ml}$ of DMSO. These discs were placed on the surface of the media. The positive control antibiotics viz., chloramphenical $(10 \mu \mathrm{g})$ were maintained. Then the Petri dishes were incubated at $37+0.5{ }^{\circ} \mathrm{C}$ for 12 to 14 hours. The diameters of inhibition zones were measured. (Bauer etal.,1966).

\section{RESULTS}

Aqueous, petroleum ether, ethanol and methanol leaves extracts of $S$. nux vomica was assessed for antibacterial (Table 1). The results showed that among the four extracts, methanol showed significant result of antibacterial activity. When compared with other extracts, aqueous extract showed minimum level of inhibition. Among the seven bacterial strains, maximum zones were observed in the following bacterial strains such as $B$. subtilis, P. aeruginosa and E. coli. S. paratyphi- $b$ were found to be highly susceptible to methanol extract. The inhibition zone of methanol extract was similar to that of the control, chloramphenical.

Table 1. Antibacterial activity of various solvent leaves extracts of Strychnos nux vomica.

\begin{tabular}{|c|c|c|c|c|c|c|}
\hline \multirow{3}{*}{$\begin{array}{l}\text { S. } \\
\text { No. }\end{array}$} & \multirow{3}{*}{ Microorganisms } & \multicolumn{5}{|c|}{ Zone of Inhibition (mm) } \\
\hline & & \multicolumn{4}{|c|}{ Various solvent extracts used $(\mathrm{mg} / \mathrm{ml})$} & \multirow{2}{*}{$\begin{array}{c}\text { Control } \\
\text { Chloramphenical }\end{array}$} \\
\hline & & Aqueous & Petroleum Ether & Ethanol & Methanol & \\
\hline 1. & Bacillus subtilis & 9 & 11 & 10 & 14 & 15 \\
\hline 2. & Escherichia coli & 10 & 12 & 11 & 17 & 21 \\
\hline 3. & $\begin{array}{l}\text { Pseudomonas } \\
\text { aeruginosa }\end{array}$ & 9 & 11 & 9 & 12 & 16 \\
\hline 4. & Salmonella paratyphi $b$ & 8 & 13 & 7 & 11 & 12 \\
\hline
\end{tabular}

\section{DISCUSSION}

The results showed that the aqueous, petroleum ether, ethanol and methanol leaves extracts of $S$. nux vomica has revealed a significant results of antibacterial activity when compared with other extracts except aqueous showed minimum level of inhibition. Among all the bacterial strains, maximum zones were observed in the following bacterial strains such as B.subtilis, P. aeruginosa and E. coli. S. paratyphi- $b$ were found to be highly susceptible to methanol extract. Plant extracts are potential sources of novel anti-microbial compounds especially against bacterial pathogens. Phytomedicine can be used for the treatment of diseases as in case of Unani and Ayurvedic system of medicine or it could be the base for the development of medicine, a natural blue print for the development of a drug (Didry et al., 1988). The plant extracts were screened against human pathogenic bacteria to check antibacterial activities by agar well diffusion method, which showed valuable zone of inhibition. Specifics zone of inhibition against different types of pathogenic bacteria (Alam Morshed et al., 2011). Our study contradicted the earlier reports of Gnanavel et al (2012).

\section{CONCLUSION}

In the present study indicated a significant antibacterial activity effect of the leaf extracts of
Strychnos nux vomica and exposes the existing potential of the other parts of the tree to be explored for other medicinal benefits of the human kind.

\section{REFERENCES}

Alam Morshed, M., U. Azim and R. Akhlaqur, (2011). In vitro antimicrobial and Cytotoxicity screening of Terminalia arjuna ethanol extract. Int. J. Biosci.1:31:38.

Balick, M.J., Micheal Fredi Kronenberg, Andreana, Lososki Marian Reiff, Adriane tugh Berinan, Bonnie 0' Connor, Maria, Roble, Patricia Lohr and Daniel Atha, (2000). Medicinal Plants used by latino healer's for women's health conditions in New York 54(3):343-357.

Bauer, A.W., W.M. M. Kirby, J.C. Sherris and M. Turck, (1966). Antibiotic susceptibility testing by a standardized single disk method. Am. J. Clin. Pathol. 45:493 - 496.

Dennis, P.A. (1988). Herbal Medicine among the Miskito of Eastern Nicaragua, Econ. Bot. 42(1):16-28.

Didry, N., L. Dubreuil, F. Trotin, and M. Pinkas, (1988). Antimicrobial activity of the aerial parts of Drosera pellata smith on oral bacteria. J. Ethnopharmacol. 60:91-96. 
Dubey, D., M.C. Sahu, S. Rath, B.P. Paty, N.K. Debata and R.N. Padhy. (2012). Antimicrobial activity of Strychnos nux vomica seed extract. Asian Pac. J. Trop. Biomed. S846-S854.

Gnanavel, S., R. Bharathidasan, R. Mahalingam, P. Madhanraj and A. Panneerselvam, (2012). Antibacterial and antifungal activity of
Strychnos nux vomica seed extract. Asian J. Pharm. Tech., 2(1):08-11.

Sereiti Al, M.R., K.M. Abu-Amer and P. Sen, (1999). Pharmacology of (Rosemary. Rosmerinus officinatis, Linn), and its therapeutic potentials, Ind. J. Exp. Biol. 37:124-130. 